\title{
Anticonvulsant Activity of Methanol Stem Bark Extract of Securinega Virosa (Euphobiaceae) in Mice.
}

\author{
${ }^{1}$ Tanko, Y., ${ }^{1}$ Eze, E. D. 1 Jimoh, A., ${ }^{1}$ Yusuf, M., ${ }^{1}$ Mohammed, K. A., ${ }^{3}$ Balarabe,F., \\ ${ }^{2}$ M. G. Magaji And ${ }^{1}$ Mohammed, A. \\ ${ }^{I}$ Department of Human Physiology, Faculty of Medicine, Ahmadu Bello University, Zaria,Nigeria. \\ ${ }^{2}$ Department of Pharmacology and Therapeutics, Ahmadu Bello University, Zaria, Nigeria \\ ${ }^{3}$ Department of Nursing Sciences, Faculty of Medicine, Ahmadu Bello University, Zaria, Nigeria
}

\begin{abstract}
The anticonvulsant property of methanol stem bark extract of Securinega virosa was evaluated in Pentylenetetrazole and 4-aminopyridine-induced seizure in mice. To achieve this aim twenty five animals were grouped into five groups of $(n=5)$ each. Group I served as a negative control and receive distilled water, Group II to IV were administered with $12.5,25.0$ and $50 \mathrm{mg} / \mathrm{kg}$ bw of the extract while Group V received standard drug Valproic acid 200mg/kg $b \mathrm{w}$ respectively intraperitoneally. The onset of convulsion and mortality were determined. The results of this study showed that stem bark extract of Securinega virosa offered protections (80 and 20\%) at the doses administered (12.5 and $25 \mathrm{mg} / \mathrm{kg} b \mathrm{w}$ ) and (20\%) at a tested dose (50mg/kg $\mathrm{b} w$ ) in Pentylenetetrazole and 4-aminopyridine induced seizure, implying that $12.5 \mathrm{mg} / \mathrm{kg}$ bw exhibited a higher protective activity. This suggests that then plant extract possesses bioactive constituents that may be beneficial in the management of epilepsy and lend credence to the traditional use of this plant in management of epilepsy.
\end{abstract}

Key words: Convulsion, Epilepsy, Mice, Pentylenetetrazole, Securinega virosa, seizure

\section{Introduction}

Convulsion is a pathological body condition characterized by abdominal, violent and uncontrolled spasmodic contractions and relaxations of the voluntary muscles. Convulsion is often interchangeably with seizure, although there are many types of seizure, some of which have subtle or mild symptoms instead of convulsions. Epilepsy is the second most common neurological disorder after stroke, effecting at least 50 million persons worldwide and approximately $40 \%$ of them are women [1]. Epilepsy shows a prevalence rate in $1-2 \%$ of the world population [2]. Seizures of all types are caused by disorganized and sudden electrical activity in the brain [3]. Epilepsy is a chronic and often progressive disorder characterized by the periodic and unpredictable occurrence of epileptic seizures, i.e., involuntary contraction of striated muscle repeatedly. Convulsion arises due to sudden excessive and rapid discharge of cerebral neurons in the grey matter of the brain [4]. There is a pressing need for new anticonvulsants for children and adults with medically refractory epilepsy [5]. The strategies for the development of antiepileptic drugs have heavily relied on the basic premise that epilepsies are due to an imbalance between excitatory and inhibitory transmission in the brain [6]. Epileptic drug therapy in most patients is based on experimental seizure classification, because diversitycauses the seizure drugs to be less specific for each of these effects. About $1 \%$ of people are born with epilepsy and approximately $10 \%$ of the population will experience a seizure. Although, by standard treatment in $80 \%$ of the seizure can be controlled, nevertheless the millions of people have uncontrolled epilepsy [7]. Plants have been major sources of medicine and plant secondary metabolite has been attributed for most plants' therapeutic activities [8]. Securinega virosa is one of the great African medicinal plants described as a true "cure all", of which all parts are used as remedies, particularly the root [9] - [10]. In Nigeria, it is found in virtually all parts of the country. In many parts of Africa including the north Eastern Nigeria, the root and leafy twig decoctions are used for the treatment of epilepsy. It is a dense, low branching, many branched shrub, sometimes a small spreading tree up to about $6 \mathrm{~m}$ high, although, more commonly 2 to $3 \mathrm{~m}$, evergreen or deciduous [9]. It is widely distributed throughout tropical Africa, also in India, Malaya, China and Australia [11]. The root is used in many parts of Africa in the treatment of fever, body pain, stomach ache rheumatism, diarrhoea, pneumonia and epilepsy [9][12]. Hence, this study was aimed at assessing the anticonvulsant activity of methanol stem bark extract of Securinega virosa in Pentylenetetrazole and 4-aminopyridine-induced seizure in mice

\section{Materials And Methods}

2.1 Location and duration of the study

This study was carried out at the Animal House of the Department of Human Physiology, Faculty of Medicine, Ahmadu Bello University, and Zaria Kaduna, Nigeria in the month of February, 2008. 


\subsection{Drugs}

These include: Pentylenetetrazole $(9.0 \mathrm{mg} / \mathrm{kg}), 4$-aminopyridine $(1.5 \mathrm{mg} / \mathrm{kg})$, Valproic acid $(200$ $\mathrm{mg} / \mathrm{kg}$ ) and phenobarbitone $(20 \mathrm{mg} / \mathrm{kg})$. Other chemicals used were of analytical grade.

\subsection{Collection of plant material}

The whole plant, Securinega virosa was collected from Basawa town, Sabon gari Local Government Area, zaria Kaduna State in the month of January, 2007. The plant was identified and uthenticated by Mallam Umar Gallah of the Herbarium section of the Department of Biological Sciences, Ahmadu Bello University, zaria where a voucher specimen number (918) was deposited.

\subsection{Extraction of plant material}

The stem bark of the plant was cleaned and the bark removed separately. They were air dried under shade and then milled into coarse powder of $100 \mathrm{~g}$. The powdered stem bark was macerated in $500 \mathrm{ml}$ of methanol with ocassional shaking to obtain the dried extract of $8.5 \%$. The extract was stored in a desiccator until it was reconstituted in an appropriate volume.

\subsection{Animal management and care}

Swiss albino mice $(20-30 \mathrm{~g})$ of either sex were obtained from the Animal house facility of the Department of Pharmacology and Clinical Pharmacy, Ahmadu Bello University, Zaria, Nigeria. They were housed in standard cages and kept under controlled room temperature in a $12 \mathrm{~h}$ light-dark cycle. The animals were fed on standard feeds (Vital feeds, Jos Nigeria) and allowed access to water ad libitum.

\subsection{4-aminopyridine -induced Seizure in mice}

\section{Experimental Procedures}

The method described by Yamaguchi and Rogawski (1992) [13] was employed. A total of twenty five (25) mice were used in this study, Group I received $10 \mathrm{ml}$ of distilled water Group II received $12.5 \mathrm{mg} / \mathrm{kg} \mathrm{b}$ w of S.virosa ip, Group III received $25 \mathrm{mg} / \mathrm{kg}$ b w of $S$. virosa ip, Group IV received $50 \mathrm{mg} / \mathrm{kg} \mathrm{b} \mathrm{w} \mathrm{of} S$. virosa ip and Group V received $30 \mathrm{mg} / \mathrm{kg} \mathrm{b} \mathrm{w}$ of phenobarbitone (standard drug). Thirty (30) minutes after the administration with the above doses of plant extract of $S$. virosa, convulsions was induced with using 4aminopyridine $(1.5 \mathrm{mg} / \mathrm{kg} \mathrm{b} \mathrm{w})$ subcutaneously and were observed over a period of 30 minutes. Absence of an episode of clonic spasm of at least 5 seconds duration indicated the extract's ability to abolish the effect of 4 aminopyridine on seizure threshold and mortality was observed and recorded.

\subsection{Pentylenetetrazole-induced Seizure in mice}

In this study, twenty five (25) mice were assigned into different groups as follows: Group I received 0 $\mathrm{ml}$ of distilled water, Group II received $12.5 \mathrm{mg} / \mathrm{kg} \mathrm{b} \mathrm{w}$ of S.virosa ip, Group III received $25 \mathrm{mg} / \mathrm{kg} \mathrm{b} \mathrm{w} \mathrm{of} S$. virosa ip, Group IV received $50 \mathrm{mg} / \mathrm{kg} \mathrm{b}$ w of $S$. virosa ip, Group V received $200 \mathrm{mg} / \mathrm{kg}$ b w of Valproic acid (standard drug). Thirty (30) minutes after treatment, the animals induced with pentylenetetrazole $(9.0 \mathrm{mg} / \mathrm{kg} \mathrm{b}$ w). The onsets of seizure and mortality rate were evaluated [14].

\subsection{Statistical Analysis}

Data obtained were statistically analyzed using one-way analysis of variance (ANOVA) with Tukey's multiple comparison post hoc tests to compare the level of significance between control and experimental groups. All statistical analysis was evaluated using SPSS version 17.0 software. The values of $\mathrm{p}<0.05$ were considered as significant [15].

\section{Results And Discussion}

\subsection{Effect of Methanol stem bark extract of Securinega virosa on 4-aminopyridine-induced seizure in} mice

"TABLE" 1 showed that the plant extract exhibited $20 \%$ protection against the 4 -aminopyridineinduced seizure at a dose of $50 \mathrm{mg} / \mathrm{kg} \mathrm{b}$ w and significantly $(\mathrm{p}<0.05)$ prolonged the onset of seizure from $10 \pm$ 1.10 mins $14.7 \pm 4.40$ mins in mice when compared. However, the extract at dose levels of $12.5 \mathrm{and} 25 \mathrm{mg} / \mathrm{kg}$ b w did not protect the animals against 4-aminopyridine -induced seizure.

\subsection{Effect of Methanol stem bark extract of Securinega virosa on Pentylenetetrazole -induced seizure in mice}

"TABLE" 2 showed the control group animal exhibited generalized myoclonic body twitches, generalized body seizure with loss of right reflex with tonic forelimb extension and loss in the pentylenetetrazole-induced seizure with a mean of $10.0 \pm 3.1$ (mins) and offered $0 \%$ protection to the animals with $60 \%$ mortality rate recorded. The study revealed that the 12.5 and $50 \mathrm{mg} / \mathrm{kg} \mathrm{b}$ w of Securinega virosa 
significantly $(\mathrm{P}<0.05)$ prolong the onset of pentylenetetrazole-induced seizure from $10.0 \pm 3.1$ (mins) to $14.0 \pm 0.0$ and $16.30 \pm 5.9$ and offered 80 and $0 \%$ protection and 20 and $0 \%$ mortality respectively compared with the control (Table 2). The extract at dose level of $25 \mathrm{mg} / \mathrm{kg}$ bw did not protect the animals against pentylenetetrazole-induced seizure and $100 \%$ mortality recorded.

Table 1: Effect of Methanol stem bark extract of Securinega virosa on 4-aminopyridine-induced seizure in mice

\begin{tabular}{llll}
\hline Treatment given & $\begin{array}{l}\text { Mean onset of seizure } \\
(\text { mins })\end{array}$ & $\begin{array}{l}\text { Percentage protection } \\
(\%)\end{array}$ & Mortality (\%) \\
\hline Control+distilled water & $10.0 \pm 1.10$ & 0.0 & 0.0 \\
$12.5 \mathrm{mg} / \mathrm{kg} \mathrm{b} \mathrm{w}$ & $8.6 \pm 0.70^{\mathrm{ns}}$ & 0.0 & 0.0 \\
$25 \mathrm{mg} / \mathrm{kg} \mathrm{b} \mathrm{w}$ & $10.8 \pm 3.10^{\mathrm{ns}}$ & 0.0 & 0.0 \\
$50 \mathrm{mg} / \mathrm{kg} \mathrm{b} \mathrm{w}$ & $14.7 \pm 4.40^{\mathrm{a}}$ & 20 & 80 \\
$20 \mathrm{mg} / \mathrm{kg} \mathrm{b}$ w of & - & 100 & 0.0
\end{tabular}

Phenobarbitone

${ }^{a} \mathrm{p}<0.05$ is statistically significant when compared to control group, while $\mathrm{ns}=$ not significant when compared to the control group

Table 2: Effect of Methanol stem bark extract of Securinega virosa on Pentylenetetrazole -induced seizure in mice

\begin{tabular}{llll}
\hline Treatment given & $\begin{array}{l}\text { Mean onset of seizure } \\
\text { (mins) }\end{array}$ & $\begin{array}{l}\text { Percentage protection } \\
(\%)\end{array}$ & Mortality (\%) \\
\hline Control + & $10.0 \pm 3.10$ & 0.0 & 60 \\
distilled water & & & 20 \\
$12.5 \mathrm{mg} / \mathrm{kg} \mathrm{b} \mathrm{w}$ & $14.0 \pm 0.0^{\mathrm{a}}$ & 80 & 20 \\
$25 \mathrm{mg} / \mathrm{kg} \mathrm{b} \mathrm{w}$ & $7.3 \pm 2.7^{\mathrm{ns}}$ & 20 & 100 \\
$50 \mathrm{mg} / \mathrm{kg} \mathrm{b}$ w & $16.3 \pm 5.9^{\mathrm{a}}$ & 0.0 & 0.0 \\
$200 \mathrm{mg} / \mathrm{kg} \mathrm{b}$ w of & - & 100 &
\end{tabular}

Valproic acid

${ }^{\mathrm{a}} \mathrm{p}<0.05$ is statistically significant when compared to control group, while $\mathrm{ns}=$ not significant when compared to the control group

\section{Discussion}

The 4-aminopyridine and Pentylenetetrazole (PTZ) models are widely believed to be predictive of activity in common form of human epilepsy [16] - [17]. The anticonvulsant activities of stem bark extract of Securinega virosa were investigated by the pentelenetetrazole- and 4-aminopyridine-induced seizure models. Prevention of seizures induced by pentelenetetrazole in laboratory animals is the most commonly used preliminary screening test for characterizing potential anticonvulsant drugs [18]. Generally, compounds with anticonvulsant activity in the petitmal epilepsy are effective in pentelenetetrazole-induced seizure model [19]. The study showed that the extract at 12.5 and $25 \mathrm{mg} / \mathrm{kg} \mathrm{b}$ w did not protect the animals against PTZ-induced seizure. However, the extract at dose level of $50 \mathrm{mg} / \mathrm{kg} \mathrm{b}$ w offered $20 \%$ protection and significantly prolonged the onset of seizure in mice when compared to the control group. Anticonvulsant activity in pentylenetetrazole test identifies compounds that can raise seizure threshold in the brain [20]. Pentylenetetrazole has been shown to interact with GABA neurotransmitters and the GABA receptor complex. Antagonism of PTZ-induced seizures suggests effects on GABA-ergic neurotransmission. The anticonvulsant activity of the extract against PTZ-induced seizures suggests that the extract may be effective in the therapy of absence or myoclonic seizures by modifying excitatory and inhibitory neurotransmission through effects on voltage gated ion channels, GABA (A) receptors and glutamate mediated excitatory neurotransmission [21]. 4-Aminopyridine is a known potassium channel blocker [13]. The study revealed that the extract exhibited $20 \%$ protection against the 4 aminopyridine-induced seizure at a dose of $50 \mathrm{mg} / \mathrm{kg} \mathrm{b} \mathrm{w}$ and prolonged the onset of seizure from in mice when compared. However, the extract at dose levels of 12.5 and $25 \mathrm{mg} / \mathrm{kg} \mathrm{b} \mathrm{w}$ did not protect the animals against 4-aminopyridine -induced seizure. The absence of anticonvulsant activity against 4-AP induced seizures suggests that the extract may not have activity against potassium channels.

\section{Conclusion}

From the above study it was concluded that, the methanol stem bark extract of Securinega virosa exhibits anticonvulsant activity and the probable mode of action may be due to GABA aminergic mediation and glutamate mediated excitatory neurotransmission. 


\section{References}

[1] M.L.Scheuer and T. A. Pedley, The evaluation and treatment of seizures. New Engl J Med.; (323), 1990, 1468-74.

[2] P. Kamboj, I. Singh, N. Mahadevan and G. Chaudhary, Anticonvulsants from nature. Phcog Rev.; 3(5), 2009, 108-17.

[3] C. G. Goet and E. J. Pappert, Text book of clinical Neurology $2^{\text {nd }}$ ed. (Philadelphia, pa: Saunders, 2003).

[4] K. Suresh, M. Reecha, B. Gundeep, J. Anupam and S. Anupam, Plants and Plant Products with Potential Anticonvulsant Activity - A Review. Pharmacognosy Communications Volume (2), 2012, Issue (1) Suppl.

[5] X. Lin, R. Nicholas, Y. Xiao-Feng, X. Z. Hai, L.T. Liu, M.R. Steven, E.W. Aryan, W. Michael and A.Y. Kelvin A. Y, Leptin inhibits 4-aminopyridine- and pentylenetetrazole-induced seizures and AMPAR-mediated synaptic transmission in rodents. Journal of Clinical Investigatio, .118 (1), 2008, 272-280.

[6] A. Atif, J.A. Farhan, K .P. Krishna, and V. Divya, Amiloride protects against pentylenetetrazole-induced kindling in mice, British Journal of Pharmacology; 145(7), 2005, 880-884.

[7] J. Engel, A proposed diagnostic scheme for people with epileptic seizures and with epilepsy: report of the ILAE Task Force on Classification and Terminology. Epilepsia, (42), 2001, 796-803.

[8] P.O. Fabeku, Traditional Medicine: the art, ways and practice. In: Odugbemi, T, editor, Outlines and Pictures of Medicinal Plants from Nigeria, (University of Lagos Pres, .2006) 13-24.

[9] J.D. Neuwinger, Translated from by Porter A. African ethnobotany poison and drugs, (Chapman and Hall, Weinheim, 1996) pp. 495-499.

[10] Y. Tanko, M.A. Okasha, G. M. Magaji, M. Yerima, A.H. Yaro,M.I.A. Saleh and A. Mohammed, Anti-diabetic properties of Securinega virosa (Euphorbiaceae) leaf extract. African Journal of Biotechnology, Vol. 7 (1), 2008, pp. 022-024

[11] J. M. Dalziel, The useful plants of West Tropical Africa, (Watmonghs, Idle, London, 1936) pp. 354-355.

[12] M. G. Magaji, J.A. Anuka, I. Abdu-Aguye, A.H. Yaro and I.M. Hussaini, Preliminary studies on anti-inflammatory and analgesic activities of Securinega virosa (Euphorbiaceae) in experimental animal models. Journal of Medicinal Plants Research Vol. 2(2), 2008, pp. 039-044.

[13] S.I. Yamaguchi and M.A. Rogawski, Effects of 4-aminopyridine-induced seizure in mice. Epilepsy Research (11), 1992, 9-16.

[14] H.M. Salahdeen and O.K. Yemitan, Neuropharmacological effects of aqueous leaf extract of Bryophyllum pinnatum in mice, African J Bio Med Res, 9, 2006, 101-07.

[15] R.C. Duncan, R.G. Knapp and M.C. Miller, Test of hypothesis in population means. In: Introductory Biostatistics for the health sciences, (John Wiley and Sons Inc. NY pp, 1977) 71-96.

[16] A.D. Wickenden, Potassium channels as antiepileptic drug targets. Neuropharmacology, 43, 2002, $1055-1060$

[17] B. Maiha, M. G. Magaji, A.H. Yaro, A.H. Hamza, S.T., Ahmed and R.A. Magaji, Anticonvulsant studies on Cochlospermum tinctorium and Paullinia pinnata extracts in laboratory animals, Nig. Journ. Pharm. Sci., Vol.8 No. 1, 2009 , Pp $102-108$.

[18] R. Duraisami, D. Srinivasan and S. Ramaswamy, Anticonvulsant activity of bioflavonoid gossypin, Bangladesh Journal of Pharmacology, (4), 2009, 51-54.

[19] W. Loscher and D. Schmidt, Which animal models should be used in the search for new antiepileptic drugs? A proposal basedon experimental and clinical consideration. Epilepsy Res. (2), 1988, 145-81.

[20] H. S.White, H. H. Wolf, J. H. Woodhead and H. J. Kupferberg, The national institute of health anticonvulsant drug development program: screening for efficacy. In: French, J., Leppik, I.E., and Ditcher, M.A.(Eds). Antiepileptic drug development: Advances in Neurology, Vol.76, (Lippincott-raven Publishers, Philadelphia, 1998) Pp. 29-39.

[21] G. Sierra-Paredas, Recent advances in the neurochemistry of epilepsy. Eur Neurol Rev., 3(1), 2008, 96-8. 